\title{
Risk Assessment of the Collisions between Floating Containers and Vessels
}

\author{
Adhi Iswantoro ${ }^{a}$, Trika Pitana ${ }^{b}$, M. Badrus Zamanc and Semin ${ }^{d}$ \\ Institut Teknologi Sepuluh Nopember \\ Department of Marine Engineering \\ adhi.iswantoro@gmail.com,pitanatrika@gmail.com,drus_zaman@yahoo.com, \\ seminits@gmail.com \\ *corresponding author
}

Keywords: $\quad$ Floating Container, Navigation, Risk Assessment.

\begin{abstract}
The shipwrecks have some impact, one of which is the impact on ship navigation and the environment. An example is a shipwreck may cause disruption to another ship's voyage if the wreck is on a cruise line. The disorder can come from shipwrecks as well as their cargo, especially if it is in shallow $(<50 \mathrm{~m})$, and oil from shipwrecks can also contaminate the environment. This study discusses the impact of ship cargoes to navigation when the container floats in the sea and collides with other passing vessels. The purpose of this study was to assess risk on floating containers from shipwrecks. This study combines the probability and consequences of an event based on the Risk Acceptance Criteria. This research uses the Risk Matrix 5 x 5 to determine the level of risk. Result of this research the container re-floating is unlikely and the risks to safe navigation or shipping in the area are low and acceptable.
\end{abstract}

\section{Introduction}

Security and Safety Maritime is a very important factor to support marine transportation and prevent accidents. Shipwrecks have the potential to pollute the sea if it contains oil or other dangerous substances or materials, this has been an issue and problem since the second world war where at that time many ships were sinking and polluting the sea due to oil and chemical materials from ships. A study says that in Swedish waters there are more than 2700 dead war shipwrecks, of which 31 shipwrecks contain hazardous chemicals that can cause environmental pollution. The results of the investigation indicate if the wreck contains about 1000 to 15000 tons of oil. Another danger comes from the cargo of the ship, especially if the ship is a merchant's ship. Because the cargo of the ship can interfere with the navigation of other ships and can cause a collision. The impacts of shipwrecks vary depending on the type of ship, the size of the ship, the cause of the sinking and the location of the ship sinking. Until now there has not been a sufficiently comprehensive method to assess the environmental risks posed by shipwrecks and can be used as a reference in decision making by decision makers. There is a method for carrying out the risk management of shipwrecks used as a precautionary measure. Therefore, currently widely used semi-qualitative analysis method in conducting risk assessment [1][6][9][10]. 


\section{Method}

\subsection{Risk Acceptance Criteria}

Risk acceptance criteria in this research is using Semi Quantitative Analysis. This study combines the probability and consequences of an event based on the Risk Acceptance Criteria. This research uses the Risk Matrix 5 x 5 to determine the level of risk as shown in Table 1. Risk categories occurred are shown in Table 2 . The criteria probability of occurrence and the consequences on the ship are shown in Table 3 and Table 4, respectively [2].

Table 1: Risk Matrix

\begin{tabular}{|c|c|c|c|c|c|c|}
\hline \multirow{5}{*}{ 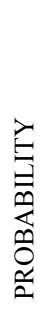 } & LEVEL 1 & 1 & 2 & 3 & 4 & 5 \\
\hline & LEVEL 2 & 2 & 4 & 6 & 8 & 10 \\
\hline & LEVEL 3 & 3 & 6 & 9 & 12 & 15 \\
\hline & LEVEL 4 & 4 & 8 & 12 & 16 & 20 \\
\hline & LEVEL 5 & 5 & 10 & 15 & 20 & 25 \\
\hline & & LEVEL 1 & LEVEL 2 & LEVEL 3 & LEVEL 4 & LEVEL 5 \\
\hline
\end{tabular}

Table 2: Description of The Risk Matrix

\begin{tabular}{|c|c|l|}
\hline Value & Classification & \multicolumn{1}{|c|}{ Description } \\
\hline 1 to 2 & Slight & No action required \\
\hline 3 to 4 & Minor & $\begin{array}{l}\text { No additional control measure are required. } \\
\text { Monitoring for change }\end{array}$ \\
\hline 5 to 9 & Moderate & $\begin{array}{l}\text { Actions can be performed under the supervision of a } \\
\text { responsible person. }\end{array}$ \\
\hline 10 to 14 & High & $\begin{array}{l}\text { Actions can be performed after the risk assessment. Mitigation } \\
\text { is required in order to qualify as ALARP }\end{array}$ \\
\hline 15 to 25 & Intolerable & Further mitigation and risk assessment are required \\
\hline
\end{tabular}

Table 3: The Criteria Probability of Occurance

\begin{tabular}{|c|l|}
\hline Level & Description \\
\hline 1 & Unlikely \\
\hline 2 & Rare \\
\hline 3 & Moderate \\
\hline 4 & Likely \\
\hline 5 & Most likely \\
\hline
\end{tabular}


Table 4:The Consequences on The Ship

\begin{tabular}{|c|l|}
\hline \multicolumn{2}{|c|}{ Level Description } \\
\hline 1 & No damage to the ship and structures \\
\hline 2 & Minor damage to the ship and structures \\
\hline 3 & Damage on the ship and structures, ship repair required \\
\hline 4 & $\begin{array}{l}\text { Mayor damage on the ship and structures, ship repair } \\
\text { required }\end{array}$ \\
\hline 5 & The damage is very serious, the ship mostly damaged \\
\hline
\end{tabular}

\subsection{Impact Energy}

Impact energy that occurs when the collision between ships that pass with containers are as follows. The collision marked by several parameters. The illustration when the collision occur as shown in Figure 2. [3].

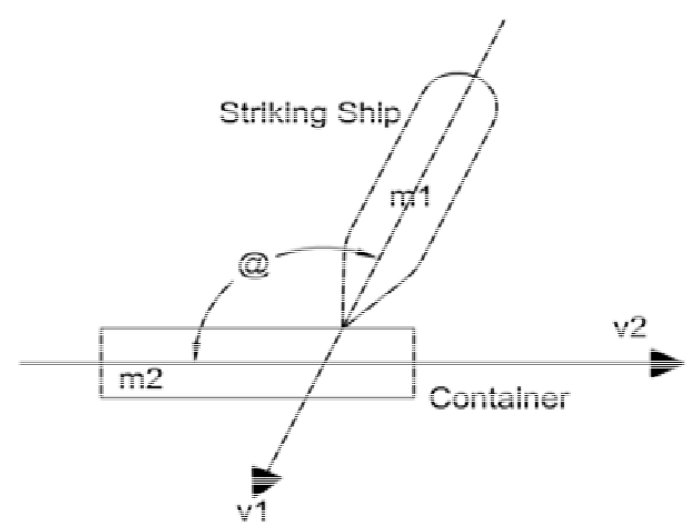

Figure 1: The illustration of collision

The following are the main parameters that influence the level of damage [3].

- Mass of ship that bumped.

- Mass of container that was hit.

- Speed of the ship that bumped.

- Speed of containers that was hit.

- Structural characteristics of ship that bumped.

- Structural characteristics of container.

- Location of collision on the ship.

From the collision scenario above then we obtained an equation as follow [3]:

$$
\Delta E k=\frac{M 1(M 2+\Delta M)}{2 M 2+M 1+\Delta M}\left(V 1 \sin \alpha^{2}\right)
$$

where:

$\Delta E k=$ absorb energy

$M 1$ = mass of ship that bumped.

$M 2$ = mass of container or wrecks that was hit.

$V 1=$ The speed of the ship that bumped.

$\Delta M=$ additional mass coefficient of container or wrecks that was hit. 


\subsection{Depth of Penetration}

The absorbed energy of an object due to the collision can result in deformation or penetration. The following is a deformation or penetration that occurs based on the number of energy absorbed in the calculation of the energy absorbed in the previous discussion. Besides using (2) and (3), also can be used Figure. 3 [8].

1) $0 \leq \Delta \mathrm{Ek} \leq 218$ ton.knot ${ }^{2}$ :

$$
\mathrm{Rt}=\Delta \mathrm{Ek} / 145
$$

2) $218 \leq \Delta \mathrm{Ek} \leq 744$ ton. $\operatorname{knot}^{2}$ :

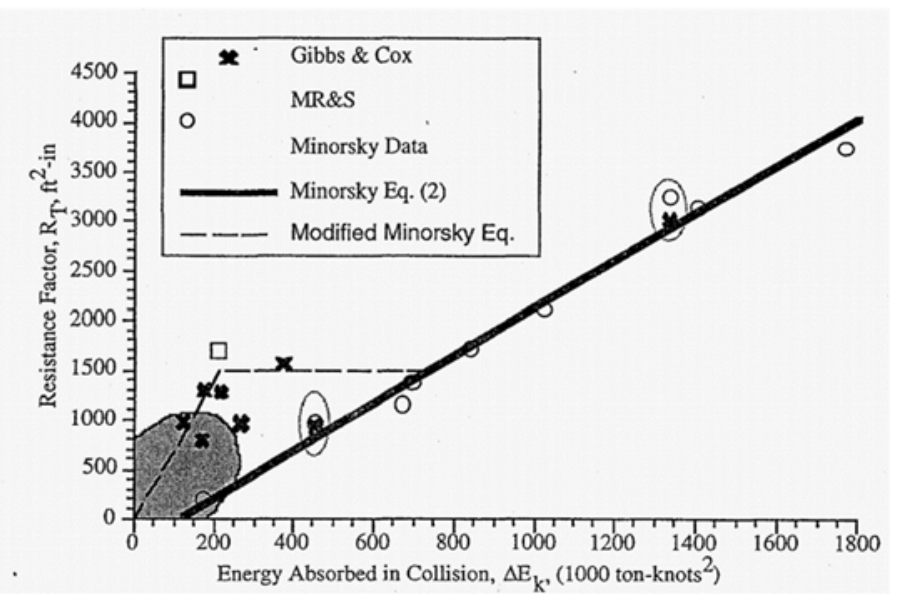

Figure 2: Minorsky Curve.

3) $\Delta \mathrm{Ek} \geq 744$ ton.knot ${ }^{2}:$

$$
\mathrm{Rt}=(\Delta \mathrm{Ek}-121.9) / 0.4145
$$

\section{Result And Discussion}

\subsection{Frequency Analysis}

A passing ship only collide with a container from the ship only if the container refloats from its location on the seabed, or on the wreck. All containers within the wreck and within the location of the wreck site would now be fully waterlogged (ie filled with water), in the process of sinking within the seafloor and possibly in the process of breaking up in the process. Therefore we can firmly state, that the sunken containers from the ship, would not float free and thus would not become a hazard for shipping, therefore the frequency analysis of a collision between ship and container below, is generally only for information and guidance on consequence should a collision had happened at the time of sinking of the ship with the floating containers and a passing ship. Other than that there is the possibility of water entering into the container so that the container is filled with water, and also the corrosion of the container that makes it damaged. Containers are weathertight, not watertight. Aluminum corrosion rate is $0.034 \mathrm{~mm} / \mathrm{year}$ and steel corrosion rate is $0.1 \sim 0.17 \mathrm{~mm} /$ year [4][5][7][11].

From this analysis, the frequency that a container will refloating from the ship wreck is unlikely (Level 1). 


\subsection{Consequence Analysis}

The consequence analysis is based on the impact the vessel received, i.e. how serious the damage occurred to the hull of the ship as it collided with the floating container. To be able to determine the level of damage to the vessel can be determined by calculating the amount of impact energy and depth of penetration.

Table 5: Ship Group

\begin{tabular}{|c|c|c|}
\hline Ship Group & $\begin{array}{c}\text { Displacement } \\
\text { (ton) }\end{array}$ & $\begin{array}{c}\text { Speed } \\
\text { (knot) }\end{array}$ \\
\hline A & 12323.12 & 10 \\
\hline B & 545.16 & 10 \\
\hline C & 6712.57 & 10 \\
\hline D & 16447.72 & 10 \\
\hline
\end{tabular}

Table 6: Container Group

\begin{tabular}{|c|c|c|}
\hline Container Group & $\begin{array}{c}\text { Weight } \\
\text { (ton) }\end{array}$ & $\begin{array}{c}\text { Drifting } \\
\text { Speed (knot) }\end{array}$ \\
\hline 20ft container & 40 & 0.5 \\
\hline 40ft container & 28 & 0.5 \\
\hline
\end{tabular}

Based on (1), the absorbed energy by ship and the absorbed energy by container are given in Table 7.

Table 7: The Absorbed Energy by Ship (Container Speed is 0,5 knots)

\begin{tabular}{|c|c|c|c|c|}
\hline \multirow{2}{*}{ Container } & \multicolumn{4}{|c|}{ Absorbed Energy (ton.knot ${ }^{2}$ ) } \\
\cline { 2 - 5 } & $\begin{array}{c}\text { Ship } \\
\text { A }\end{array}$ & $\begin{array}{c}\text { Ship } \\
\text { B }\end{array}$ & $\begin{array}{c}\text { Ship } \\
\text { C }\end{array}$ & $\begin{array}{c}\text { Ship } \\
\text { D }\end{array}$ \\
\hline 20ft container & 4.992 & 4.827 & 4.985 & 4.994 \\
\hline 40ft container & 3.496 & 3.415 & 3.493 & 3.497 \\
\hline
\end{tabular}

The absorbed energy of an object due to the collision can result in deformation or penetration. Based on (2) and (3), the penetration on the ship can be seen in Table 8. Where there are 4 types of ships used as a reference and then hit the container so that there is energy absorbed by the ship, and the energy causes damage to the hull if the ship is too large.

Table 8: Penetration on the ship (container speed 0.5 knots)

\begin{tabular}{ccccc}
\hline \multirow{2}{*}{ Container } & \multicolumn{4}{c}{ Depth of Penetration (ft' ${ }^{2}$.in) } \\
\cline { 2 - 5 } & $\begin{array}{c}\text { Ship } \\
\text { A }\end{array}$ & $\begin{array}{c}\text { Ship } \\
\text { B }\end{array}$ & $\begin{array}{c}\text { Ship } \\
\text { C }\end{array}$ & $\begin{array}{c}\text { Ship } \\
\text { D }\end{array}$ \\
\hline 20ft container & 0.0344 & 0.0333 & 0.0344 & 0.0344 \\
\hline $40 \mathrm{ft}$ container & 0.0241 & 0.0236 & 0.0241 & 0.0241 \\
\hline
\end{tabular}


Risk acceptance criteria in the study are using Semi Quantitative Analysis with Risk Acceptance Criteria. The following is the result of a risk assessment based on frequency and consequence values.

Table 9: Container Hit into Midship of Ship A-B-C-D (Drifting 0.5 Knots)

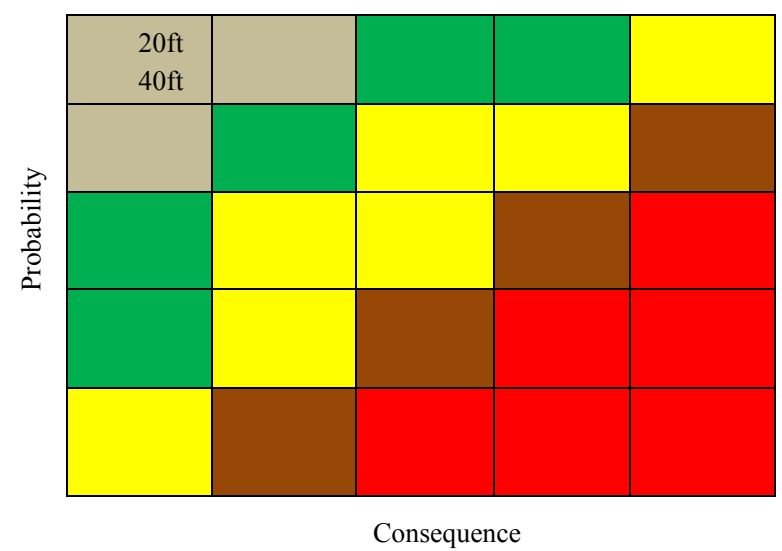

Table 10: Ship A-B-C-D Hit Into Container 0.5 Knot (vessel Speed 10 Knots)

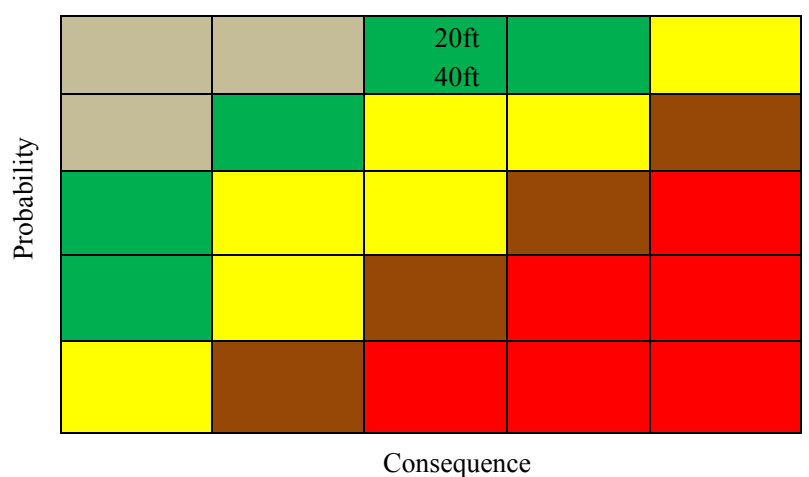

\section{Conclusion}

Based on the results of risk assessment of the floating container cargo to ship navigation can be summarized as follows:

1. The container re-floating is unlikely and the risks to safe navigation/shipping in the area are low and acceptable.

2. Based on the risk matrix, for the scenario of container hit into the ship at the speed 0.5 knots, the ship A, B, C and D, does not caused the deformation on the ship structures. So the risk matrix shows the acceptable area (low risk) for all types of containers.

3. Based on the risk matrix, for the scenario of the ship hit into the container at speed 10 knots, the ship A, B, C and D, for container $0.5 \mathrm{knot}$, does not caused the deformation on the ship structures. So the risk matrix shows the acceptable area (low risk) for all types of containers.

\section{References}

[1] Landquist, Hanna.Method Development for Environmental Risk Assessment of Shipwrecks.Goteborg, Sweden.2013.

[2] Shearman,N.Navigation Risk Assessment.Januari 2016.

[3] Kristiansen,S.Maritime Transportation Safety Management and Risk Analysis.2005.

[4] ABS Class.Rules for Certification of Cargo Containers. May 1998. 
[5] DNV-OS-C301.Stability and Watertight Integrity.April 2011.

[6] Admiralty Sailing Directions NP.34 Indonesian Pilot Vol. 2

[7] GL Class. Guidelines for the Construction, Repair and Testing of Freight Containers.April 1995.

[8] Minorsky.Momentum and Energy Principles for an Inelastic Collision of Two Bodies.1959.

[9] Peraturan Pemerintah Republik Indonesia PP No. 81 Tahun 2000 tentang Kenavigasian.

[10] Peraturan Menteri Perhubungan PM No. 71 Tahun 2013 tentang Salvage dan/atau Pekerjaan Bawah Air.

[11] H. Landquist, I.-M. Hassellöv, L. Rosén, J.F. Lindgren, I. Dahllöf. Evaluating the needs of risk assessment methods of potentially polluting shipwrecks. Gothenburg, Sweden.2013. 